\title{
Efektivitas Cangkang Telur untuk Menurunkan Bilangan Peroksida dan Asam Lemak Bebas pada Minyak Jelantah
}

\author{
Fauzi Abdilah*,Mentik Hulupi
}

Jurusan Teknik Kimia, Politeknik Negeri Bandung, Bandung, 40559, Indonesia

\begin{tabular}{l} 
I N F O A R T I K E L \\
\hline Diterima 18 Oktober 2020 \\
Disetujui 25 Oktober 2020 \\
\\
\hline Key word: \\
Adsorbent \\
Eggshell \\
Used cooking oil \\
Free fatty acids \\
Peroxide number \\
\hline Kata kunci: \\
Adsorben \\
Cangkang telur \\
Minyak jelantah \\
Asam lemak bebas \\
Bilangan peroksida
\end{tabular}

${ }^{*}$ e-mail:

fauzi.abdilah@polban.ac.id

\begin{abstract}
A BSTRACT
Used cooking oil contains various impurities that can cause various health and environmental problems. In this study, used cooking oil was purified to reduce free fatty acid levels and peroxide numbers using eggshell-based adsorbents at various calcination temperatures. The adsorbent preparation process was performed using an electric furnace for 2 hours at a temperature of 200, 400, 600 and $800^{\circ} \mathrm{C}$. The adsorption process was operated for 1 hour with stirring. The analysis carried out in this study was an analysis of the quality of the adsorbent and the characterization of functional groups using FTIR (Fourier-transform infrared spectroscopy). Analysis of free fatty acid levels and peroxide numbers was carried out by titration method. The results showed that the CTA adsorbent at a calcination temperature of $8000 \mathrm{C}$ (AE800) gave the best adsorbent quality. The results of characterization using FTIR showed a new peak at wave number $3640 \mathrm{~cm}^{-1}$. The measurement results of free fatty acid levels and the AE800 adsorbent peroxide numbers reached $54.74 \%$ and $65.79 \%$, respectively. The results of this study indicate that the calcination temperature greatly affects the characteristics of the adsorbent and eggshell has the potential to be developed as an adsorbent to improve the quality of used cooking oil and raw material for making $\mathrm{CaO}$-based catalysts.
\end{abstract}

\section{A B STRAK}

Minyak jelantah mengandung berbagai pengotor yang dapat menyebabkan berbagai masalah kesehatan dan lingkungan. Pada penelitian ini dilakukan pemurnian minyak jelantah untuk menurunkan kadar asam lemak bebas dan bilangan peroksida dengan menggunakan adsorben berbasis cangkang telur ayam (CTA) pada berbagai variasi temperatur kalsinasi. Proses persiapan adsorben dilakukan dengan menggunakan furnace elektrik selama 2 jam pada suhu 200, 400, 600 dan $800^{\circ} \mathrm{C}$. Proses adsorpsi dilakukan selama 1 jam dengan pengadukan. Analisis yang dilakukan pada penelitian ini adalah analisis kualitas adsorben dan karakterisasi gugus fungsi dengan menggunakan FTIR (Fourier-transform infrared spectroscopy). Analisis kadar asam lemak bebas dan bilangan peroksida dilakukan dengan metode titrasi. Hasil penelitian menunjukkan bahwa adsorben CTA pada suhu kalsinasi 800oC (AE800) memberikan kualitas adsorben terbaik. Hasil karakterisasi menggunakan FTIR menunjukkan adanya puncak baru pada bilangan gelombang $3640 \mathrm{~cm}^{-1}$. Hasil pengukuran kadar asam lemak bebas dan bilangan peroksida adsorben AE800 mencapai 54,74\% dan 65,79\%. Hasil penelitian ini menunjukkan bahwa temperatur kalsinasi sangat mempengaruhi karakteristik adsorben dan CTA memiliki potensi untuk dikembangkan sebagai adsorben untuk meningkatkan kualitas minyak jelantah dan bahan baku pembuatan katalis berbasis $\mathrm{CaO}$.

\section{Pendahuluan}

Minyak jelantah atau minyak goreng bekas merupakan limbah minyak goreng dari proses penggorengan. Peningkatan produksi dan konsumsi minyak goreng setiap tahun berdampak secara langsung pada meningkatnya produksi minyak jelantah. Konsumsi minyak goreng di Indonesia sangat tinggi, pada bulan maret 2019, diperkirakan produksi minyak goreng di Indonesia mencapai 
1,9 juta ton [1]. Indonesia memproduksi sekitar 3.072 juta liter minyak goreng bekas setiap tahun [2].

Minyak jelantah dapat menyebabkan masalah lingkungan jika dibuang tanpa penanganan. Organisasi Kesehatan Dunia (WHO) melaporkan bahwa 1 liter minyak jelantah dapat mencemari 1000 liter air. Selain itu, pada sistem pengolahan limbah adanya minyak jelantah menyebabkan penurunan kinerja drainase dan peningkatan konsumsi energi (diperkirakan 25\%) [3,4].

Minyak jelantah tidak layak untuk dikonsumsi atau digunakan kembali untuk memasak karena dapat menyebabkan berbagai masalah kesehatan [5]. Pada saat proses pemanasan minyak goreng, beberapa senyawa peroksida dan hidroperoksida serta asam lemak bebas akan terbentuk. Senyawa-senyawa ini menurunkan kualitas minyak secara singnifikan serta sangat berbahaya bagi kesehatan, Minyak jelantah memiliki bau yang kurang sedap disebabkan karena terbentuknya senyawa aldehid, keton, asam karboksilat dan alkohol akibat oksidasi dari asam lemak bebas pada minyak jelantah.

Walaupun konsumsi minyak goreng di Indonesia cukup tinggi, belum ada upaya sistematis yang dikembangkan untuk mengumpulkan dan memanfaatkan kembali minyak jelantah. Padahal minyak jelantah memiliki potensi yang cukup besar jika digunakan pada proses produksi biodiesel dan berbagai senyawa kimia lain yang bermanfaat. Potensi biodiesel berbasis minyak jelantah di Indonesia mencapai 1,2 milyar liter setiap tahun [2].

Minyak jelantah mungkin memerlukan pretreatment agar dapat digunakan sebagai bahan baku pada proses produksi biodiesel. Kandungan zat pengotor pada minyak jelantah misalnya asam lemak bebas (FFA atau free fatty acid) dan air. Kadar FFA yang tinggi akan mengganggu proses transesterifikasi untuk menghasilkan biodiesel. Sehingga, kualitas biodiesel menjadi rendah.

Berdasarkan hal ini, maka diperlukan upaya untuk mengurangi kadar asam lemak bebas dan bilangan peroksida pada minyak jelantah. Minyak jelantah yang diolah juga dapat dimanfaatkan sebagai bahan baku pada proses transesterifikasi untuk memproduksi biodiesel. Dengan demikian diharapkan dapat mengurangi berbagai masalah kesehatan dan lingkungan yang terkait dengan konsumsi dan pembuangannya ke sistem drainase.

Salah satu metode peningkatan kualitas minyak jelantah adalah adsorpsi. Berbagai penelitian telah melaporkan efektivitas karbon aktif sebagai adsorben pada proses adsorpsi zat pengotor [6]. Beberapa biomassa dari limbah pertanian, produk samping industri, dan bahan-bahan alam juga telah dipelajari sebagai adsorben [7,8].

Kulit telur adalah produk sampingan dari industri kue dan bahan pangan. Kulit telur ayam biasanya terdiri dari tiga bagian (bahan keramik ada di kutikula luar, lapisan kenyal (berkapur) dan bagian dalam lapisan pipih) [9].

Beberapa penelitian telah melaporkan potensi cangkang telur sebagai adsorben pada proses pengolahan limbah. Kandungan logam berat seperti besi, kadmium, kromium, dan tembaga pada air limbah dapat dikurangi dengan penambahan cangkang telur ayam sebagai adsorben. Kemampuan adsorpsi dapat meliputi beberapa mekanisme seperti adsorpsi kimia, kompleksasi, koordinasi, pertukaran ion, adsorpsi fisik, dan presipitasi [10].

Sampai saat ini, belum dilaporkan pengaruh temperatur pemanasan cangkang telur dan aktivasinya pada kemampuan adsorpsi kulit telur untuk menghilangkan kotoran dari limbah minyak. Pada penelitian ini, cangkang telur ayam digunakan sebagai bahan baku pembuatan adsorben yang akan diaplikasikan pada proses pemurnian minyak jelantah. Proses pengeringan dan pemanasan cangkang telur pada berbagai suhu diharapkan dapat meningkatkan kemampuan adsorpsi adsorben sehingga dapat menurunkan kadar asam lemak bebas dan bilangan peroksida pada sampel minyak. Karakterisasi gugus fungsi pada adsorben dilakukan dengan menggunakan FTIR (Fourier-transform infrared spectroscopy) sedangkan analisis kadar asam lemak bebas dan bilangan peroksida dilakukan secara titrasi sesuai AOCS (American Oil Chemists' Society).

Penelitian ini merupakan penelitian tahap awal untuk meningkatkan kualitas minyak jelantah. Di mana minyak hasil perlakuan dapat 
digunakan sebagai bahan baku pada proses transesterifikasi untuk menghasilkan FAME (fatty acid methyl ester), sehingga dapat dimanfaatkan sebagai biodiesel ataupun produk turunan lainnya.

\section{Bahan dan Metode}

Fokus penelitian ini adalah untuk melakukan peningkatan kualitas minyak jelantah dengan memanfaatkan cangkang telur ayam (CTA) sebagai adsorben. Adapun tahapan penelitian ditunjukkan pada Gambar 1.
Bahan yang digunakan pada penelitian ini antara lain cangkang telur ayam, minyak jelantah, asam asetat (Merck), etanol (Merck, $99,9 \%), \mathrm{KOH}$ (Merck), kloroform, $\mathrm{Na}_{2} \mathrm{~S}_{2} \mathrm{O}_{3}, \mathrm{KI}$, indikator fenolftalein, indikator amilum, akuades.

Peralatan yang digunakan pada penelitian ini adalah oven laboratorium (Memmert), furnace elektrik (Nabertherm), desikator, hotplate stirrer, dan berbagai alat-alat gelas umum di laboratorium.

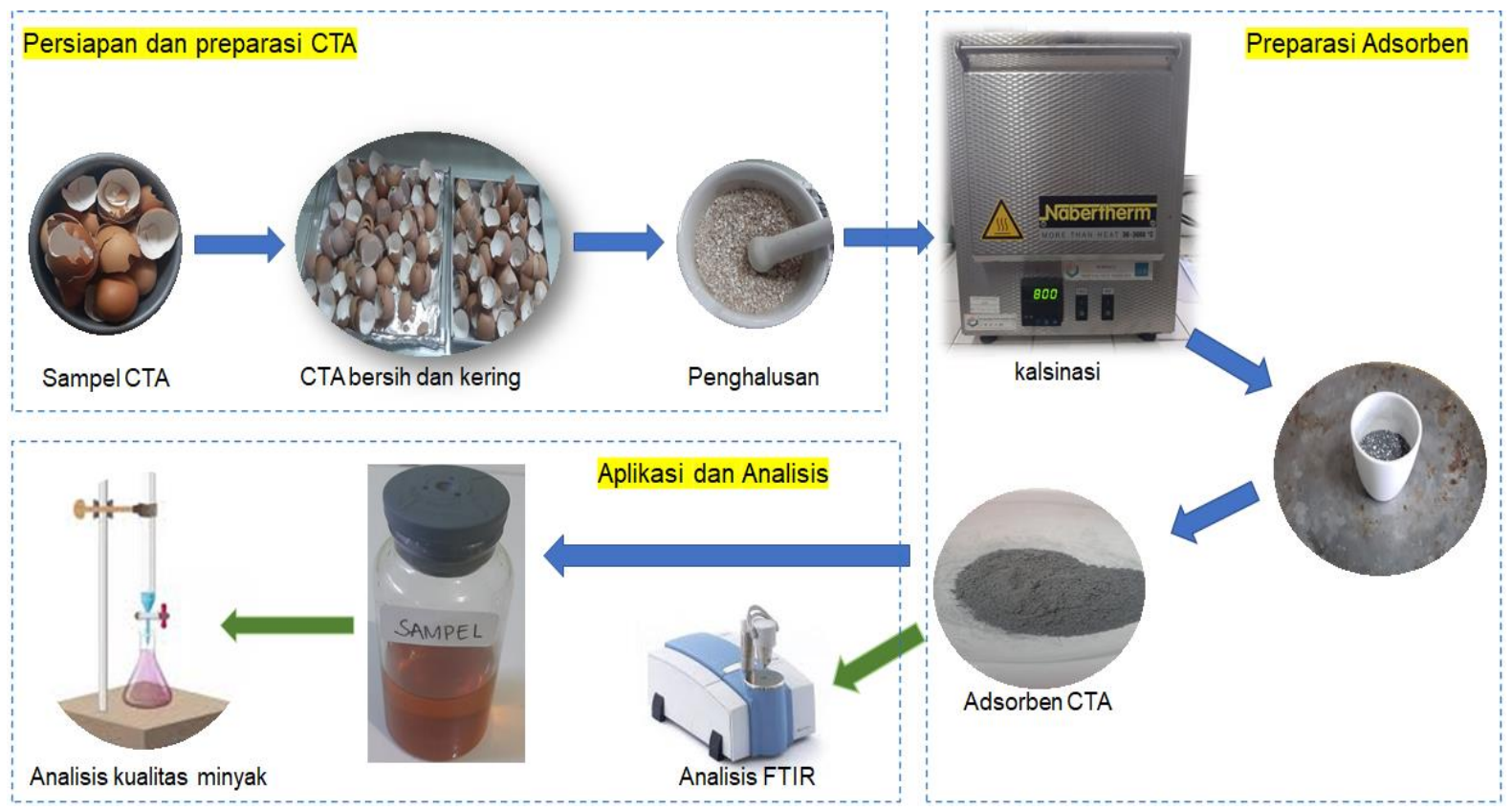

Gambar 1. Diagram proses percobaan

\section{Preparasi CTA dan Pembuatan Adsorben}

Preparasi cangkang telur dengan cara mencuci bersih cangkang telur dari kotoran dan lapisan membran yang menempel pada cangkang, kemudian dikeringkan di dalam oven pada suhu $105^{\circ} \mathrm{C}$ selama 12 jam. Selanjutnya cangkang telur dihaluskan dengan menggunakan mortar dan diayak hingga diperoleh serbuk cangkang lolos 100 mesh. Selanjutnya $15 \mathrm{~g}$ serbuk cangkang dimasukkan ke dalam cawan porselin dan dipanaskan pada berbagai variasi suhu $\left(200^{\circ} \mathrm{C}, 400^{\circ} \mathrm{C}, 600^{\circ} \mathrm{C}\right.$ dan $800^{\circ} \mathrm{C}$ ) selama $2 \mathrm{jam}$. Serbuk adsorben disimpan pada desikator sampai akan digunakan.

\section{Preparasi Sampel}

Sampel minyak jelantah yang dikumpulkan disaring untuk memisahkan pegotor padat dan disimpan dalam wadah tertutup. Sebelum digunakan, dilakukan analisis bilangan peroksida dan kadar asam lemak bebas.

Proses pemurnian minyak jelantah secara adsorpsi Sebanyak $100 \mathrm{ml}$ minyak jelantah dimasukan ke dalam gelas kimia kemudian ditambahkan $5 \mathrm{~g}$ serbuk adsorben dan diaduk selama 1 jam. Kemudian campuran disaring dengan menggunakan penyaring vakum dan 
kertas kertas whataman No 42. Filtrat yang diperoleh dianalisis kadar asam lemak bebas dan bilangan peroksidanya.

\section{Analisis Kualitas Adsorben}

Adsorben yang diperoleh dikarakterisasi dengan menggunakan FTIR dan dilakukan analisis kadar air dan daya serap iodium sesuai dengan SNI 06-3730-1995. Selain itu, dilakukan juga pengukuruan kehilangan berat dengan menggunakan metode gravimetri.

Analisis Kadar Asam Lemak Bebas

Analisis kadar asam lemak bebas dilakukan berdasarkan Metode AOCS Ca 5a-40. Sampel sebanyak $2 \mathrm{~g}$ dimasukkan ke dalam labu erlenmeyer $250 \mathrm{ml}$, ditambahkan $50 \mathrm{ml}$ alkohol netral 95\% kemudian dipanaskan dalam penangas air sampai terbentuk larutan homogen (pada suhu $60^{\circ} \mathrm{C}$ selama kurang lebih 15 menit). Larutan didinginkan dan ditambahkan 3 tetes indikator fenolftalein kemudian dititrasi dengan larutan $\mathrm{KOH} \mathrm{0,1} \mathrm{N}$ sampai terjadi perubahan warna menjadi merah jambu. Perhitungan kadar asam lemak bebas (\%) menggunakan persamaan 1. Dengan $\mathrm{NKOH}$ adalah normalitas $\mathrm{KOH}(\mathrm{N}), \mathrm{VKOH}$ adalah volume $\mathrm{KOH}$ untuk titrasi $(\mathrm{ml})$ dan Wsampel adalah berat sampel (g).

$$
\% \text { Asam Lemak Bebas }=\frac{\mathrm{N}_{\mathrm{KOH} \times \mathrm{V}_{\mathrm{KOH}} \times 0,256}}{\mathrm{~W}_{\text {sampel }}}
$$

\section{Analisis Bilangan Peroksida}

Analisis bilangan peroksida dilakukan berdasarkan Metode AOCS Cd 8-53. Sampel sebanyak $5 \mathrm{~g}$ dimasukkan ke dalam labu erlenmeyer $250 \mathrm{ml}$, ditambahkan $30 \mathrm{ml}$ larutan asam asetat;kloroform (3:2), diaduk sampai homogen, kemudian ditambahkan $0,5 \mathrm{ml}$ larutan KI jenuh dan diaduk lagi. Ke dalam erlenmeyer tersebut ditambahkan $30 \mathrm{ml}$ akuades. Larutan kemudian dititrasi dengan larutan $\mathrm{Na}_{2} \mathrm{~S}_{2} \mathrm{O}_{3}$ 0,01 N sampai warna kuning pucat lalu ditambahkan $0,5 \mathrm{ml}$ indikator amilum $1 \%$ dan dititrasi sampai warna biru mulai hilang. Perhitungan bilangan peroksida (meq/kg) menggunakan persamaan 2. Dengan $\mathrm{NNa} 2 \mathrm{~S} 2 \mathrm{O} 3$ adalah normalitas $\mathrm{Na} 2 \mathrm{~S} 2 \mathrm{O} 3(\mathrm{~N})$, VNa2S2O3 adalah volume $\mathrm{Na} 2 \mathrm{~S} 2 \mathrm{O} 3(\mathrm{ml})$, dan Wsampel adalah berat sampel (g).

Bilangan Peroksida $=$

$$
\frac{\mathrm{V}_{\mathrm{Na} 2 \mathrm{~S} 2 \mathrm{O} 3} \times \mathrm{N}_{\mathrm{Na} 2 \mathrm{~S} 2 \mathrm{O} 3}}{\mathrm{~W}_{\text {sampel }}} \times 1000
$$

\section{Hasil dan Pembahasan}

Tahap awal dari penelitian ini adalah pembuatan adsorben berbasis cangkang telur ayam melalui proses pengeringan dan pemanasan. Adapun gambar cangkang telur sebelum dan setelah pengeringan pada berbagai variasi temperatur ditampilkan pada Gambar 2.

Berdasarkan hasil yang diperoleh dapat terlihat adanya perubahan warna CTA akibat perlakuan suhu. Semakin tinggi temperatur kalsinasi, semakin banyak oksida logam yang terbentuk. Pada saat proses kalsinasi, $\mathrm{CaCO} 3$ pada CTA akan terkonversi menjadi $\mathrm{CaO}$. Hasil penelitian Zaman dkk., menunjukkan bahwa derajat kristalinitas $\mathrm{CaO}$ tertinggi terjadi pada temperatur kalsinasi $800^{\circ} \mathrm{C}$ [11]. Pada suhu dibawah $600^{\circ} \mathrm{C}$, dekomposisi senyawa organik pada CTA belum sempurna [12].

Persamaan reaksi dekarbonasi yang terjadi pada suhu $800^{\circ} \mathrm{C}$ ditunjukkan pada persamaan 3. Sedangkan reaksi transformasi $\mathrm{CaO}$ akibat uap air ditunjukkan pada persamaan 4 .

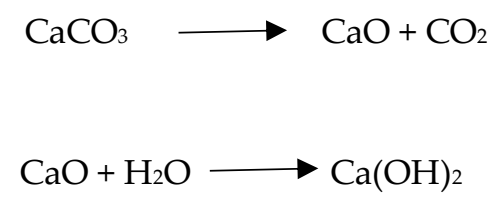




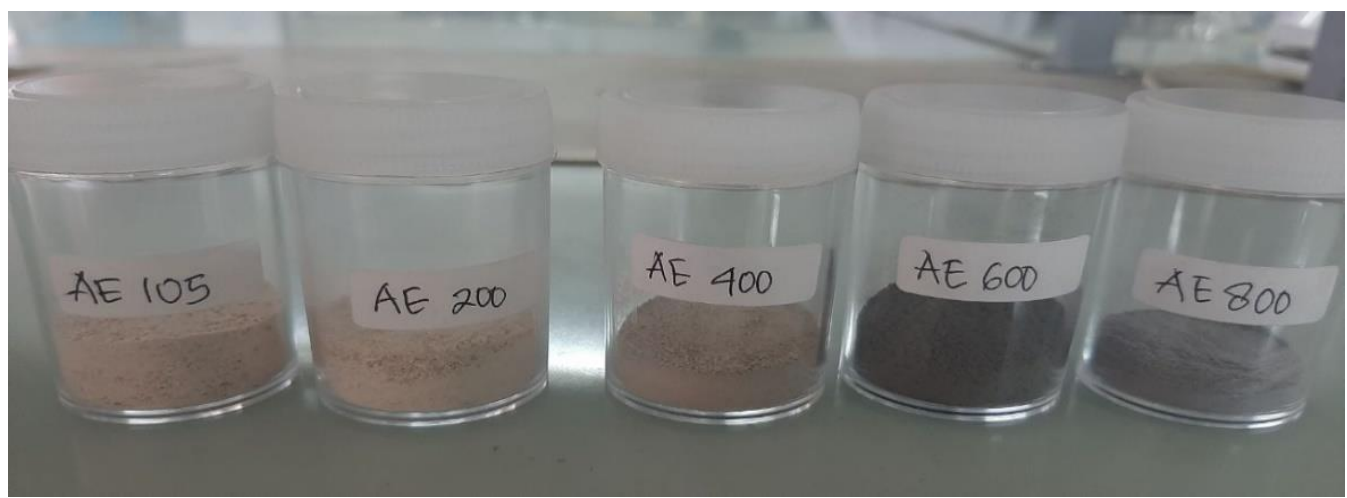

Gambar 2. Serbuk cangkang telur setelah pengeringan selama 2 jam pada suhu: $105^{\circ} \mathrm{C}$ (AE105), $200^{\circ} \mathrm{C}$ (AE200), $400^{\circ} \mathrm{C}(\mathrm{AE} 400), 600^{\circ} \mathrm{C}(\mathrm{AE} 600)$ dan $800^{\circ} \mathrm{C}$ (AE800)

\section{Uji Kualitas Adsorben}

Pada penelitian ini, setelah diperoleh serbuk cangkang telur ayam pada berbagai variasi temperatur, dilakukan karakterisasi dan pengujian kualitas adsorben CTA. Karakterisasi adsorben setelah aktivasi dilakukan dengan menggunakan FTIR untuk mengetahui gugus fungsi yang terdapat pada adsorben (gambar 3). Pengujian kualitas cangkang telur ayam sebagai adsorben dilakukan untuk mengetahui kadar air dan daya serap iodium sesuai dengan SNI 063730-1995 (tabel 1).
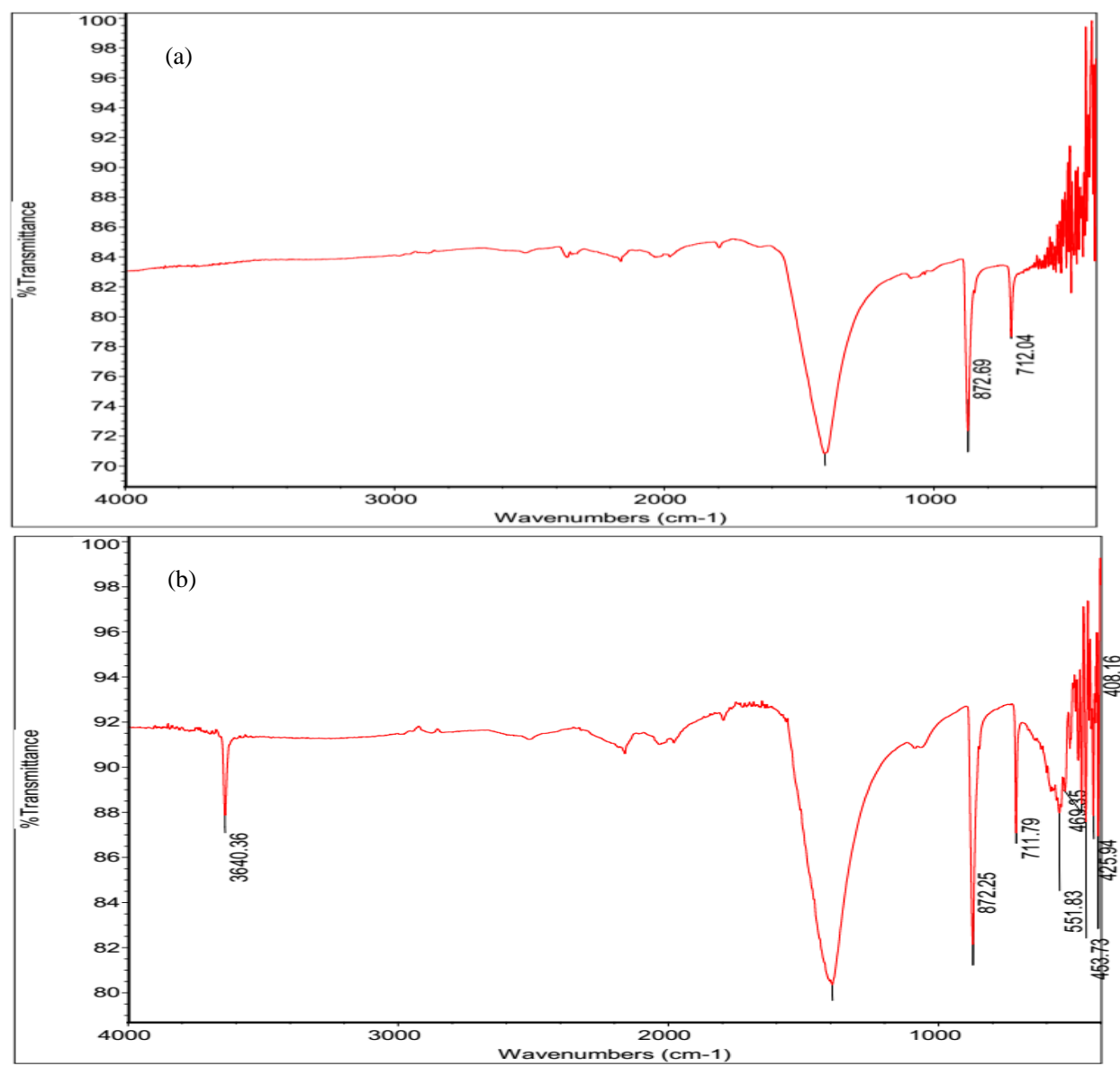

Gambar 3. Spektrum FTIR adsorben AE105 (a) dan AE800 (b) 
Tabel 1. Hasil pengujian kualitas adsorben

\begin{tabular}{lccc}
\hline $\begin{array}{c}\text { Kode } \\
\text { Adsorben }\end{array}$ & $\begin{array}{c}\text { Kadar Air } \\
\mathbf{( \% )}\end{array}$ & $\begin{array}{c}\text { Daya Serap Iod } \\
(\mathbf{m g} / \mathbf{g})\end{array}$ & $\begin{array}{c}\text { Kehilangan } \\
\text { Berat } \mathbf{( \% )}\end{array}$ \\
\hline AE105 & 18 & 755 & 14,07 \\
AE200 & 14 & 765 & 15,86 \\
AE400 & 11 & 795 & 29,12 \\
AE600 & 9 & 883 & 33,42 \\
AE800 & 5 & 932 & 39,75 \\
\hline
\end{tabular}

Berdasarkan spektrum FTIR pada gambar 3, dapat diketahui bahwa hasil analisis FTIR untuk cangkang telur sebelum dan setelah kalsinasi pada suhu $800^{\circ} \mathrm{C}$ menunjukkan perbedaan spektrum yang cukup jelas. Proses kalsinasi pada suhu $800^{\circ} \mathrm{C}$ menyebabkan terbentuknya puncak baru pada bilangan gelombang $3640 \mathrm{~cm}^{-1}$ yang menunjukkan ikatan $\mathrm{Ca}-\mathrm{O}\left(\mathrm{Ca}(\mathrm{OH})_{2}\right)$. Hasil serupa dilaporkan oleh Hakimi dkk., di mana cangkang telur yang teah diaktivasi pada suhu $800^{\circ} \mathrm{C}$ selama 2 jam memberikan puncak pada bilangan gelombang $3615 \mathrm{~cm}^{-1}$ [13]. Coreira dkk., juga melaporkan bahwa perlakuan termal terhadap cangkang telur puyuh memberikan pita hidroksil baru sekitar $3637 \mathrm{~cm}^{-1}$ yang digolongkan dalam kelompok $\mathrm{OH}$ kalsium [14]. Puncak dengan intensitas tertinggi untuk CTA dan AE800 adalah pada bilangan gelombang $1400 \mathrm{~cm}^{-1}$, hal ini disebabkan karena keberadaan mineral karbonat dalam matriks kulit telur [15]. Adanya karbonat dan terbentuknya $\mathrm{CaO}$ dari CTA membuat cangkang telur dapat dimanfaatkan pada berbagai aplikasi seperti pada proses adsorpsi maupun sebagai katalis.

Pada penelitian ini dilakukan juga penentuan kadar air untuk mengetahui sifat higroskopis dari adsorben. Semakin rendah kadar air adseorben, semakin besar pori-porinya sehingga kualitas adsorben semakin baik. Pengukuran daya serap iodium dilakukan untuk mengetahu efisiensi adsorben pada proses adsorpsi zat warna. Semakin tinggi nilai daya serap ion, semakin potensial adsorben dimanfaatkan pada proses adsorpsi. Hasil pengujian kadar air dan daya serap iodium pada Tabel 1 menunjukkan bahwa adsorben yang dihasilkan memenuhi syarat SNI 06-3730-1995 dengan kadar air $<15 \%$ dan daya serap iodin $>$ $750 \mathrm{mg} / \mathrm{g}$. Pada penelitian ini juga dilakukan pengukuran kehilangan berat untuk mengetahui. Berdasarkan hasil pengujian ini, dapat diketahui bahwa adsorben AE800 memiliki kualitas terbaik dibandingkan dengan adsorben lain.

\section{Aplikasi Adsorben pada Minyak Jelantah}

Proses adsorpsi dilakukan pada sampel minyak jelantah dengan tujuan untuk mengurangi kadar asam lemak bebas dan bilangan peroksida. Secara umum penampakan fisik minyak sebelum dan setelah adsorpsi dengan menggunakan adsorben AE800 dapat dilihat pada Gambar 4.

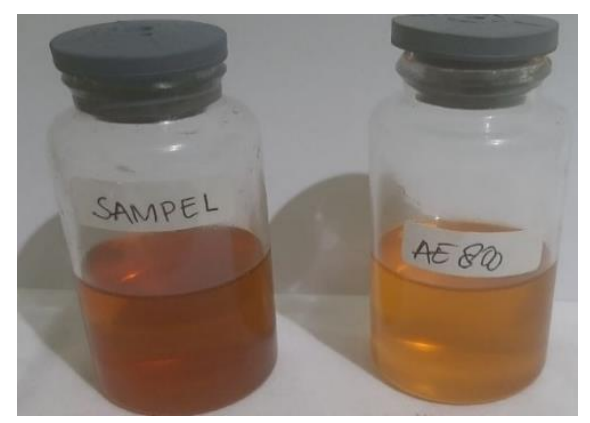

Gambar 4. Perbandingan sampel (minyak jelantah) dan minyak hasil adsorpsi selama 1 jam pada suhu $800^{\circ} \mathrm{C}(\mathrm{AE} 800)$ 
Analisis Asam Lemak Bebas

Pengujian kadar asam lemak bebas pada penelitian ini menggunakan metode titrasi. Berdasarkan hasil penelitian yang telah dilakukan maka diperoleh data seperti pada tabel 2. Secara umum dapat dilihat bahwa pemberian adsorben CTA pada sampel minyak jelantah mampu mengurangi kadar asam lemak bebas pada minyak jelantah. Penurunan kadar asam lemak bebas terbesar adalah pada penambahan adsorben AE800 yaitu mencapai $54,74 \%$, sedangkan penurunan kadar asam lemak bebas terendah adalah pada penambahan adsorben AE105, yaitu 7,17\%. Hasil analisis pada tabel 2 menunjukkan bahwa persentase penurunan kadar asam lemak bebas meningkat seiring dengan peningkatan temperatur kalsinasi. Hal ini dapat disebabkan karena pada umumnya proses kalsinasi pada suhu tinggi berdampak secara langsung pada peningkatan luas area permukaan suatu material [15].

Tabel 2. Hasil analisis kadar asam lemak bebas

\begin{tabular}{lcc}
\hline Adsorben & $\begin{array}{c}\text { Asam lemak } \\
\text { bebas (\%) }\end{array}$ & $\begin{array}{c}\text { Penurunan } \\
\text { kadar asam } \\
\text { lemak bebas (\%) }\end{array}$ \\
\hline $\begin{array}{l}\text { Tanpa } \\
\text { Adsorben }\end{array}$ & 0,1237 & - \\
AE105 & 0,1117 & $7,17 \%$ \\
AE200 & 0,0883 & $26,62 \%$ \\
AE400 & 0,0853 & $29,17 \%$ \\
AE600 & 0,0824 & $31,51 \%$ \\
AE800 & 0,0545 & $54,74 \%$ \\
\hline
\end{tabular}

Analisis Bilangan Peroksida

Pengujian bilangan peroksida pada penelitian ini dilakukan dengan metode titrasi. Hasil pengukuran penurunan bilangan peroksida ditampilkan pada tabel 3 . Penambahan cangkang telur ayam sebelum dan setelah kalsinasi sebagai adsorben pada minyak goreng bekas mampu menyerap bilangan peroksida.
Berdasarkan tabel 3 terlihat terjadi penurunan kadar bilangan peroksida pada semua variasi adsorben. Proses pemurnian minyak goreng dengan menggunakan adsorben cangkang telur ayam memberikan penurunan kadar bilangan peroksida sekitr 39,47\% $65,79 \%$. Berdasarkan hasil ini, maka dapat dilihat bahwa adsorben AE800 memberikan nilai penurunan kadar bilangan peroksida tertinggi, yaitu mencapau $65,79 \%$, sedangkan hasil pengurangan bilangan peroksida terendah adalah pada penggunaan AE105 (CTA tanpa kalsinasi).

Tabel 3. Hasil analisis bilangan peroksida

\begin{tabular}{lcc}
\hline Adsorben & $\begin{array}{c}\text { Bilangan } \\
\text { Peroksida } \\
(\mathrm{meq} / \mathrm{kg})\end{array}$ & $\begin{array}{c}\text { Penurunan } \\
\text { kadar Bilangan } \\
\text { Peroksida (\%) }\end{array}$ \\
\hline Tanpa & 7,4708 & - \\
Adsorben & & \\
AE105 & 4,5218 & $39,47 \%$ \\
AE200 & 3,5388 & $52,63 \%$ \\
AE400 & 3,1456 & $57,89 \%$ \\
AE600 & 2,9498 & $60,53 \%$ \\
AE800 & 2,5558 & $65,79 \%$ \\
\hline
\end{tabular}

\section{Ucapan Terima Kasih}

Ucapan terima kasih disampaikan kepada UPPM Politeknik Negeri Bandung telah memberikan bantuan dalam penelitian ini.

\section{Kesimpulan}

Berdasarkan hasil penelitian yang telah dilakukan dapat disimpulkan bahwa cangkang telur ayam dapat digunakan sebagai adsorben untuk meningkatkan kualitas minyak jelantah. Proses kalsinasi cangkang telur ayam pada temperatur $800 \mathrm{oC}$ memberikan hasil penurunan kadar asam lemak bebas dan penuruanan bilangan peroksida terbaik, yaitu mencapai $54,74 \%$ dan $65,79 \%$. Hasil analisis FTIR dari CTA menunjukkan potensi CTA untuk dapat diaplikasikan pada bidang lain, misalnya sebagai sumber $\mathrm{CaO}$ dan sebagai katalis pada berbagai proses kimia. 


\section{Daftar Pustaka}

1. Kementerian Perdagangan Republik Indonesia, "Analisis Perkembangan Harga Bahan Pangan Pokok di Pasar Domestik dan Internasional," 2019, pp. 1-118.

2. Kharina A, Searle S, Rachmadini D, Kurniawan AA, And Prionggo A. The potential economic, health and greenhouse gas benefits of incorporating used cooking oil into Indonesia's biodiesel. White Pap. 2018.

3. Kalam MA, Masjuki HH, Jayed MH, Liaquat AM. Emission and performance characteristics of an indirect ignition diesel engine fuelled with waste cooking oil. Energy. 2011, 36(1):397-402. doi:10.1016/j.energy.2010.10.026

4. Martínez J, Murillo Villuendas R, García T. Production of carbon black from the waste tires pyrolysis. 2013, (i).

5. Perumalla Venkata R, Subramanyam R. Evaluation of the deleterious health effects of consumption of repeatedly heated vegetable oil. Toxicol Reports. 2016, 3:636643. doi:10.1016/j.toxrep.2016.08.003

6. Anastopoulos I, Bhatnagar A, Hameed BH, Ok YS, Omirou M. A review on wastederived adsorbents from sugar industry for pollutant removal in water and wastewater. J Mol Liq. 2017, 240:179-188. doi:10.1016/j.molliq.2017.05.063

7. Zhang S, Liu S, Yu D, Wang C, Li Q. Preparation and characterization of activated carbon for separation of $\mathrm{CO} 2$. Zhongguo Kuangye Daxue Xuebao/Journal China Univ Min Technol. 2014, 43(5):910914.

8. Bae W, Kim J, Chung J. Production of granular activated carbon from foodprocessing wastes (walnut shells and jujube seeds) and its adsorptive properties. J Air Waste Manag Assoc. 2014, 64(8):879886. doi:10.1080/10962247.2014.897272

9. Didar Z. Removal of impurities from waste oil using eggshell and its active carbon. J Adv Env Heal Res. 2017, 5:123-130. doi:10.22102/JAEHR.2017.74840.1007

10. Pettinato M, Chakraborty S, Arafat HA, Calabro' V. Eggshell: A green adsorbent for heavy metal removal in an MBR system.
Ecotoxicol Environ Saf. 2015, 121:57-62. doi:10.1016/j.ecoenv.2015.05.046

11. Zaman T, Mostari MS, Mahmood MA Al, Rahman MS. Evolution and characterization of eggshell as a potential candidate of raw material TT - Evolução e caracterização da casca de ovo como potencial candidata de matéria-prima. Cerâmica. 2018, 64(370):236-241.

12. Chraibi S, Moussout H, Boukhlifi F, Ahlafi $\mathrm{H}$, Alami M. Utilization of Calcined Eggshell Waste as an Adsorbent for the Removal of Phenol from Aqueous Solution. J Encapsulation Adsorpt Sci. 2016, 06(04):132-146. doi:10.4236/jeas.2016.64010

13. Ahmadzadeh-Hakimi K, Keshmirizadeh E, Modarress H. The Activation of Eggshell by Chemical and Thermal Treatment for Removal of Acid blue 92 Dye from Aqueous Solutions. Anal Chem Lett. 2017, 7(3):369-382.

doi:10.1080/22297928.2017.1322535

14. Correia LM, Cecilia JA, RodríguezCastellón E, Cavalcante CL, Vieira RS. Relevance of the Physicochemical Properties of Calcined Quail Eggshell $(\mathrm{CaO})$ as a Catalyst for Biodiesel Production. J Chem. 2017, 2017. doi:10.1155/2017/5679512

15. Carvalho J, Araujo J, Castro F. Alternative low-cost adsorbent for water and wastewater decontamination derived from eggshell waste: An overview. Waste and Biomass Valorization. 2011, 2(2):157-167. doi:10.1007/s12649-010-9058-y

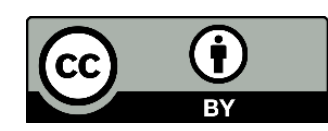

(C) 2020 by the authors. Licensee Fullerene Journal Of Chem. This article is an open access article distributed under the terms and conditions of the Creative Commons Attribution (CC BY) license (http://creativecommons.org/licenses/by/4.0/). 